\title{
Comparative Analysis of the Radiopacity of MTA and Portland Cement in Conventional and Digital Radiographic Systems
}

\section{Análise Comparativa da Radiopacidade do MTA e Cimento Portland nos Sistemas Radiográficos} Digitais e Convencionais

Carolina dos Santos Guimarães ${ }^{1}$, Ana Paula Veras Sobral ${ }^{2}$, Ricardo Ferreira Pedrosa ${ }^{3}$, Luciano Barreto Silva ${ }^{4}$, Márcia Maria Fonseca da Silveira ${ }^{5}$

\section{Resumo}

Objetivo: $O$ presente estudo teve como objetivo avaliar a radiopacidade do Agregado de trióxido mineral (MTA) e Cimento Portland $(\mathrm{PC})$ em imagens radiográficas convencionais e digitais a fim de verificar se estão em conformidade com a especificação ANSI / ADA.

Materiais e Métodos: Cinco corpos de prova para cada material com $10 \mathrm{~mm}$ de diâmetro, $1 \mathrm{~mm}$ de espessura e um penetrômetro foram expostos a $70 \mathrm{kVp}, 8 \mathrm{~mA}$ a uma distância foco-filme de $30 \mathrm{~cm}$. Os tempos de exposição foram 0,4 e 0,2 s para o filme Insight Kodak e sistema digital CR Kodak 7400, respectivamente. A densidade óptica foi medida na radiografia através de um fotodensitômetro e o valor de pixel foi obtido para as imagens digitais. Um gráfico dos valores obtidos versus mmAl foi elaborado a fim de gerar uma curva de radiopacidade dos degraus do penetrômetro, obtendo a correspondência em equivalência de mmAl dos materiais estudados Um gráfico foi feito para os valores medidos em comparação mmAl, a fim de gerar uma curva de radiopacidade dos passos penetrômetro, obtendo-se a correspondência de equivalência de mmAl dos materiais estudados.

Resultados: O teste estatístico de Mann-Whitney mostrou diferença estatística significativa na radiopacidade entre MTA e PC, tanto no sistema convencional (valor $p=0,009$ ) e digital(valor $p=0,009$ ). $O$ mesmo teste também mostrou diferença estatística significativa entre os sistemas convencionais e digitais em ambos os materiais $(p=$ 0,016 valueMTA-e $p$-valuecp $=0,009$ ).

Conclusões: MTA e CP não apresentaram radiopacidade dentro dos padrões exigidos pela especificação $\mathrm{N} \circ 57$ do American National Standards / American Dental Association.

Palavras-chave: materiais dentários; radiografia; Radiografia dentária, digital.

\footnotetext{
Abstract

Objective: The present study aimed to evaluate the radiopacity of Mineral Trioxide Aggregate (MTA) and Portland Cement (PC) in conventional and digital radiographic images in order to verify if they are in accordance with ANSI/ADA specification.

Materials and Methods: For each material five test specimens with $10 \mathrm{~mm}$ of diameter, $1 \mathrm{~mm}$ of thickness and a stepwedge were exposed at $70 \mathrm{kVp}, 8 \mathrm{~mA}$ and focal distance of $30 \mathrm{~cm}$. Exposure times were 0,4 and 0,2 s for Kodak Insight film and Kodak CR 7400 digital system, respectively. The optic density was measured in the radiograph using a photo-densitometer and the value of pixel was obtained for digital images. A graph was made for measured values versus $\mathrm{mmAl}$ in order to generate a radiopacity curve of the stepwedge steps, obtaining the correspondence in equivalence of $\mathrm{mmAl}$ of the studied materials.
}

Rev. Fac. Odontol. Porto Alegre, v. 51, n. 3, p. 11-15, set./dez., 2010.

\author{
1 Mestre em Endodontia pela Faculdade de Odontologia de Pernambuco/ \\ Camaragibe-PE \\ ${ }^{2}$ Doutora em Patologia Oral pela Universidade de São Paulo e Professora Adjunta \\ da Faculdade de Odontologia de Pernambuco/ Camaragibe-PE \\ ${ }^{3}$ Doutor em Dentística pela Faculdade de Odontologia de Pernambuco/ Camaragibe- \\ PE \\ 4 Mestre em Endodontia pela Faculdade de Odontologia de Pernambuco - \\ Camaragibe-PE \\ ${ }^{5}$ Doutora em Estomatologia Biologia Oral pela Universidade de São Paulo e \\ Professora Adjunta da Faculdade de Odontologia de Pernambuco/Camaragibe-PE
}

Correspondência: Carolina dos Santos Guimarães

Endereço: Rua Gervásio Fioravante, 87, apto 402 - Graças, CEP 52011-030, Recife - PE, Brasil

Fone: (81) 3222-6390 / 9232-3932

E-mail: carolina.odontologia@gmail.com

Data de Submissão: 22/07/2011

Data de Aceite: 09/05/2012

Results: The statistical Mann-Whitney test showed statistical significant difference in the radiopacity between MTA and PC in both conventional ( $p$ value $=0,009)$ and digital $(p$ value $=0,009)$ systems. The same test also showed statistical significant difference between conventional and digital systems in both materials ( $p$-value MTA $=0,016$ and $p$-value cp $=0,009)$.

Conclusions: MTA and CP did not show radiopacity inside of the standards demanded by specification $\mathrm{N}^{\circ} 57$ of the American National Standards/ American Dental Association.

Keywords: dental materials; radiography; radiography, dental, digital.

\section{Introduction}

Mineral trioxide aggregate (MTA) was presented as a promising new material in 1993 by Torabinejad. Because of its excellent physical, chemical and biological properties, it has been widely used for root-end fillings, pulp capping, perforation repairs, and other endodontic procedures. However; it was noticed, in previous research studies, that Portland Cement (PC), which is used in civil construction, had similar characteristics to those of MTA, except for bismuth in its composition, which confers radiopacity ${ }^{1}$.

Bernabé and Holland (2003) claimed that PC radiopacity was inadequate for use in dentistry. Radiopacity is a physical property essential for endodontic materials because it makes possible to identify the material inside the tooth (ABREU; TAVARES; VIEIRA, 1977).

Digital image represents a great advance for diagnosis, since it allows additional information when compared to conventional radiographies. Therefore, there has been increasing offers of digital systems. Therefore, there have been innumerable studies comparing 
the digital systems to conventional radiographic films, as well as comparing the digital systems among themselves in order to assess the quality of the image in terms of perception of contrasts, performance of the observer in the diagnosis, exposure dose and properties of the images. However, when comparing studies that evaluated the radiopacity of materials using different systems, it is necessary to understand the effect that a particular methodology may exert on the results (HEHN et al., 2007).

There are few studies concerning the radiopacity of MTA and or PC using the aluminum reference (mmAl) (LEITES et al., 2008). The American National Standards of American Dental Association (ANSI/ADA) (2006) states that endodontic filling materials must present an equivalent radiopacity of not less than $3 \mathrm{~mm}$ of aluminum.

The present study aimed to evaluate the radiopacity of MTA and $\mathrm{PC}$ in both digitized and digital radiographic images in order to verify if they are in accordance with ANSI/ADA specification.

\section{Materials and Methods}

This research was developed at the Department of Nuclear Energy/Federal University of Pernambuco (UFPE). Five specimens of each material (MTA - Angelus ${ }^{\circledR}$, Londrina, PR, Brasil and PC II - F32, Zebu Cimpor Cimentos do Brasil, João Pessoa, PB, Brasil) were prepared according to manufacturer's directions and placed into a $10 \mathrm{~mm}$ diameter and $1 \mathrm{~mm}$ thickness ring. All the sperimens had heen radiographed (Spectro 70X, Dabi Atlante) at $i \ldots \ldots, \ldots . . ., \ldots \ldots$ filtration equivalent to $2.71 \mathrm{~mm}$ aluminum and $30 \mathrm{~cm}$ focal distance. The exactness, precision and reproducibility of the X-ray device were previously evaluated using a RMI 242 (Gammex Inc., Middleton, WI, USA). A ten step $99.5 \%$ of pureness aluminum stepwedge which thicknesses increasing of $2 \mathrm{~mm}$ and a squared area of at least $4 \mathrm{~mm}$ of edge was exposed together with the specimens. Also, a square lead plate of $1 \mathrm{~cm}^{2}$ and $1 \mathrm{~mm}$ thickness for reading of base-plus-fog density was added.

The sets formed by specimens of tested materials, aluminum stepwedge and lead plate were irradiated over Insight E/F occlusal films (Kodak Eastman Company, Rochester, New York, NY, USA) on a support of styrofoam for $0.4 \mathrm{~s}$ (Figure 1 ).

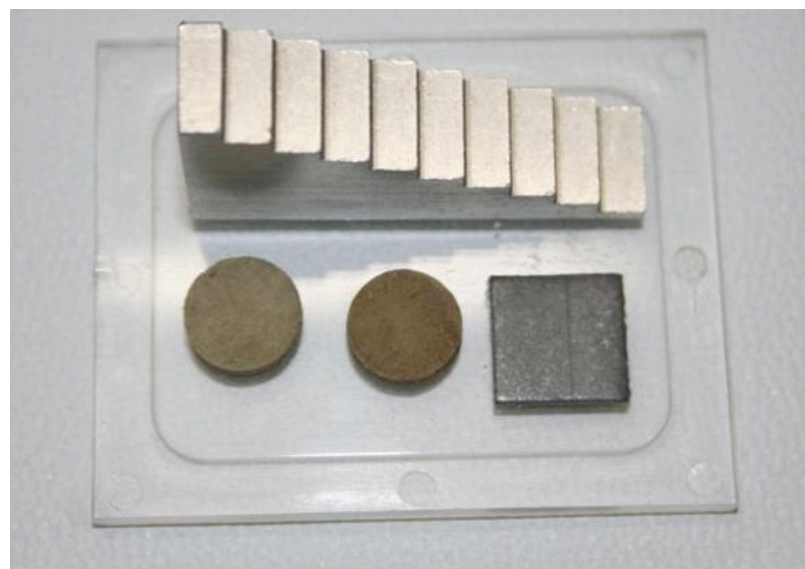

Figure 1: Specimens, aluminum step wedge and lead plate.

The films had been processed using ready for use solutions (Kodak Eastman Company, Rochester, New York, NY, USA) through temperature/time method in portable darkroom (Del Grandi Radiological products Ltda, São Paulo, SP, Brazil).For digital images the sensor Kodak (CR 7400 digital system) and experimental arrangement were exposed for $0.2 \mathrm{~s}$.
The optic densities had been measured in the conventional images (Figure 2) using a densitometer M.R.A., model 07-443 (Victoreen Inc, Cleveland, $\mathrm{OH}, \mathrm{USA}$ ) with a $2 \mathrm{~mm}$ opening, calibrated on the basis of the manufacturer's specifications. Initially, the reading of the base of the film, also called reading of base-plus-fog density (BFD) was made. Afterwards, the measurement of the optic densities (OD) of the tested material specimens and aluminum stepwedge were obtained. With these measurements, it was possible to calculate the value of the liquid optic density (LOD) of each material and of the steps through the formula:

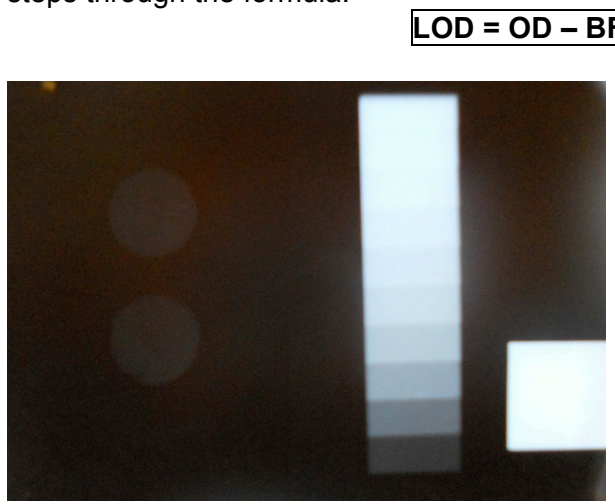

Figure 2: Conventional exposure

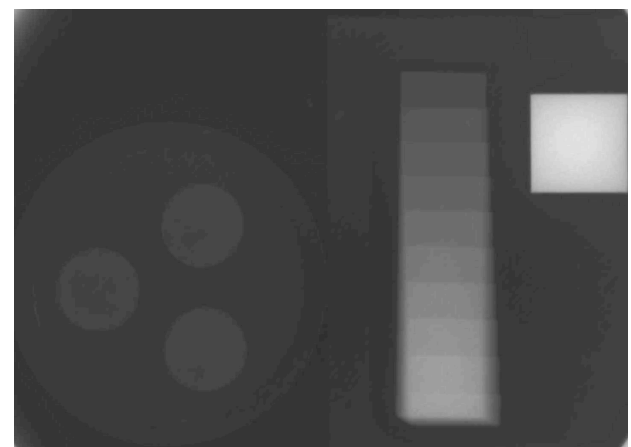

Figure 3: Exposure Kodak CR 7400 digital system

The digital images (Figure 3) were assessed using the mean pixel value in Image $\mathrm{J}$ software, using the Analyze set measurements function.

For each exposition, a graph of the LOD versus mmAl was plotted for the conventional radiographies and a graph of the inverse of the value of pixel versus mmAl for the digital system in Microsoft Excel 2003 Software (Microsoft, Seattle, Washington, USA), obtaining the curve of radiopacity of steps from step wedge, objectifying through an equation, to get the value in equivalence of $\mathrm{mmAl}$ of the studied materials.

For the confection of the curves, a mathematical approach was made, through a curve of exponential trend and, with the objective of this curve passed through the highest number of possible points, obtaining a value of R2 next to one.

In opposition to the measurements of the density in the radiographies, where the darkest areas register the highest values, in the digital images the darkest areas register the lowest ones. To get the same type of curve, the values of white are inverted (gray inversion or pixel value), transforming them into black through the equation:

Average value of pixel $=\mathbf{2 5 5}-$ value of pixel 
For each curve an equation with exponential trend was generated

\section{$\mathrm{Y}=\mathrm{a} \cdot \exp ^{-(\mathrm{bx})}$}

Being $\mathbf{Y}$, a LOD, in radiographies, and the value of pixel, in the digital images; $\mathbf{X}$, the value of equivalence in millimeters of aluminum, $\mathbf{a}$ and $\mathbf{b}$ are parameters of regression generated for each curve. Applying the value of the LOD or value of pixel of each material, the value of equivalence in millimeters of aluminum was obtained.

The nonparametric Mann-Whitney test, with 0.05 level of significance was used to compare the values of the radiopacity in $\mathrm{mmAl}$ of the studied materials and between the results obtained from the conventional and digital systems.

\section{Results}

Table 1 display the application of Mann-Whitney test for equivalence in mmAl in accordance with the type of material. The results test showed that there had been significant statistical difference between the values of the radiopacity in mmAl of MTA and $\mathrm{PC}$ in the conventional and in the digital system.

Table 1: Values of he radiopacity in $\mathrm{mmAl}$ of MTA and PC in the conventional and in digital system.

\begin{tabular}{lccc}
\hline \multirow{2}{*}{$\begin{array}{l}\text { Statistical } \\
\text { Variables }\end{array}$} & \multicolumn{2}{c}{ Material } & p-value * \\
\cline { 2 - 3 } & $\begin{array}{c}\text { MTA } \\
\text { Mean } \pm \text { AD }\end{array}$ & $\begin{array}{c}\text { PC } \\
\text { Mean } \pm \text { AD }\end{array}$ & \\
\hline Conventional & $1,19^{\mathrm{a}} \pm 0,332$ & $0,06^{\mathrm{b}} \pm 0,033$ & 0,009 \\
Digital & $1,83^{\mathrm{a}} \pm 0,157$ & $0,64^{\mathrm{b}} \pm 0,432$ & 0,009
\end{tabular}

Mean values followed by the same superscript letter had statistically significant differences. $\alpha=.05$.

(*)Mann-Whitney test

$A D=$ average deviation

There was significant statistical difference between the conventional and digital systems in relation to the radiopacity in $\mathrm{mmAl}$ of MTA and PC.

Table 2: Conventional and digital systems in relation to the radiopacity in $\mathrm{mmAl}$ of MTA and PC.

\begin{tabular}{lccc}
\hline \multirow{2}{*}{$\begin{array}{l}\text { Statistical } \\
\text { variables }\end{array}$} & \multicolumn{2}{c}{ Radiographic system } & \\
\cline { 2 - 3 } & $\begin{array}{c}\text { Conventional } \\
\text { Mean } \pm \text { AD }\end{array}$ & $\begin{array}{c}\text { Digital } \\
\text { Mean } \pm \text { AD }\end{array}$ & \\
\hline MTA & $1,19^{\mathrm{a}} \pm 0,332$ & $1,83^{\mathrm{a}} \pm 0,157$ & 0,016 \\
PC & $0,06^{\mathrm{a}} \pm 0,033$ & $0,64^{\mathrm{a}} \pm 0,432$ & 0,009
\end{tabular}

Mean values followed by the same superscript letter had statistically significant differences. $\alpha=.05$.

$\left(^{*}\right)$ Mann-Whitney test

$\mathrm{AD}=$ average deviation

\section{Discussion}

The ideal radiopacity of dental materials is still subject of frequent discussion, since materials exhibiting little radiopacity compromise the diagnosis, because the very simple presence of them in a certain spot may be confused with cavities or untreated perforations, making it difficult to assess marginal fit and the due detection of materials in the region of injury (IMPERIANO et al., 2007). On the other hand, the excessive radiopacity may prevent the detection of marginal defects in the insertion of materials, reducing the perception of details (ESPELID et al., 1991).

Decades ago, there had been no standardization of methodology for studying the radiopacity of materials. In 1983, the specification Paragraph 57 of the ANSI / ADA was approved by the Council of Materials, Dental Instruments and Equipment. This document refers to the rules of standardization for tests on materials used in endodontic fillings. In 2006 this specification was actualized.

Endodontic filling materials should have higher radiopacity than dentin to be detected in radiographic images. From the moment the stepwedge became exposed along with the specimens, making possible to obtain values of radiopacity which could be compared with other studies, because such device aims to eliminate any external influence that might change the image, such as the electric current of the device, temperature and processing of the radiographic film (RASIMICK, 2007).

Some researches (TORABINEJAD, 1995) showed that the mean radiopacity of MTA was equivalent to $7.17 \mathrm{mmAl}$. On the other hand, a more recent study (TANOMARU et al., 2004) demonstrated that MTA-based materials had radiopacity between 2 and $4 \mathrm{mmAl}$. In this study, the MTA presented a mean radiopacity of $1,19 \mathrm{mmAl}$ in the conventional system and $1,83 \mathrm{mmAl}$ in the digital. As for what concerns PC, a study (ISLAM; CHNG; YAP, 2006) found a mean radiopacity of $0.94 \mathrm{mmAl}$. Other study (LEITES et al., 2008) observed that the radiopacity of PC was $60 \%$ of the MTA. In this research the $\mathrm{PC}$ had a mean radiopacity of $0,06 \mathrm{mmAl}$ in the conventional system and $0,64 \mathrm{mmAl}$ in the digital image. Results of studies concerning the radiopacity of materials, whether expressed in equivalent mmAl may show differences, along with the different methodologies employed. Such variations can be attributed to different thicknesses of the specimens and to the lack of the stepwedge reference.

The radiopacity of dental materials is determined by the degree of absorption of photons from the X-rays that come in contact with the matter. The higher the absorption, the greater the radiopacity and the photons that can pass through the matter, the less radiopaque the radiographic image become (TIRAPELLI et al., 2004). There are several factors that affect the absorption of X-rays, including density, atomic number and thickness of material. A denser material is also more absorbent than a less dense one because there is more mass concentrated in a certain volume. The atomic number of the material is directly proportional to its mass. The greater the atomic mass, the greater the probability of interactions between these materials, because the impact area is supposed to increase.

MTA and PC are very similar in their chemical components. They contain substances that add radiopacity to the material such as silicon, aluminum, iron, sulfur, calcium and magnesium. In both MTA and PC, there is a lack of instructions as for what concerns the ratio of the substances in the cement, which indeed is a fact that influences radiopacity. Furthermore, only MTA contains bismuth oxide in its composition, which is the far responsible for MTA's radiopacity, as a highly dense and heavy metal with atomic number 83 and atomic weight 208, 9 u (SAIDON et al., 2003). In this research MTA presented radiopacity significantly higher than $\mathrm{PC}$ in the conventional and digital radiographic systems. However both materials were far below the specifications established by Paragraph 57 of the ANSI / ADA. If bismuth is the component absent in PC whose addition would probably allow it to be used in dentistry it is only natural to speculate 
its addition so that PC would show the desired radiopacity. It was related another way which is to increase the ratio of substances such as iron, calcium and aluminum in the material (FIGUEIREDO et al., 2008). There are doubts concerning the ratio to be added in order to obtain the radiopacity which would make PC clinically feasible, since although the radiopacity is desirable to endodontic sealers, other properties such as biocompatibility, adequate consistency, marginal sealing, insolubility and resistance to body fluids must be present in these materials (RUIZ, 2003).

Frequently, in an attempt to increase the radiopacity by the addition of radiopacificators, properties essential to the sealers are changed. Studies revealed differences in the consistency and chemical composition of PC with the addition radiopacifiers. Thus, when adding a radiopacifiers, not only should the adequate substance be added, but also the ideal ratio in order to preserve the other desired properties. Therefore, more studies headed for such target are needed (MITTAL; CHANDRA; CHANDRA, 1999; TRINDADE; OLIVEIRA; FIGUEIREDO, 2003).

The thickness of the material influence on its radiopacity. Guimarães (2009) tested the radiopacity of MTA and PC using the old Standard of ANSI/ADA (AMERICAN NATIONAL STANDARD/AMERICAN DENTAL ASSOCIATION, 1983). This rule stated that the specimens should have a diameter of $10 \mathrm{~mm}$ and thickness $2 \mathrm{~mm}$. The results showed that MTA has met the standards of the norm in both digital and conventional system, since it had a radiopacity average of $7,69 \mathrm{mmAl}$ and $7,38 \mathrm{mmAl} \mathrm{mmAl}$, respectively. $\mathrm{PC}$ did not meet the standard since its radiopacity average was $2,05 \mathrm{mmAl}$ and $2,27 \mathrm{mmAl}$ in the conventional and digital system, respectively. However, this study was based on the most current standards of ANSI / ADA (AMERICAN NATIONAL STANDARD/AMERICAN DENTAL ASSOCIATION, 2006). This norm requires that endodontic sealers should have a radiopacity equivalent to at least $3 \mathrm{mmAl}$ and the specimens should have a thickness of $1 \mathrm{mmAl}$ (half that determined by the old standard). Using this methodology, MTA has not completed the requirements of the standard, since your radiopacity average was $1.19 \mathrm{mmAl}$ and $1.83 \mathrm{mmAl}$ in conventional and digital system, respectively.

The digital systems for acquisition of radiographic images present advantages when compared to conventional radiography (DOYLE; FINNEY, 2005), in spite of being more expensive. Digital systems enable a reduction of $70 \%$ of exposure dose, without altering the image quality and the use of developing solutions is not necessary. Also allow greater speed image processing and accuracy and allow the use of resources that can assist with the visualization of the radiographic image (GIUSTI; FERNANDES; MARQUES, 2007). The present study showed statistical significant difference between conventional and digital system.

The study of the radiopacity of dental materials is a continuous effort as new materials and formulations appear in the market very frequently. Although researchers attempt to standardize the studies, many times it is not possible to compare the results for the same material. The standardization of the radiopacity assessment in conventional images is already established, in a certain way, when the norms of ISO and ANSI/ADA are carried out. Therefore, for the digital systems, a need of implementation of norms do exist, so that the results can be compared. As the digital systems have gradually become a reality, it is suggested that new studies be carried out with the aim of establishing standardization for this methodology.

\section{Conclusion}

MTA showed radiopacity greater than PC. However, both did not show radiopacity within the standards demanded by specification $\mathrm{N}^{\circ} 57$ of the American National Standards/ American Dental Association (2006), in conventional and digital radiographic systems.

\section{Acknowledgments}

To Department of Nuclear Energy / Federal University of Pernambuco for the essential support in this research.

\section{References}

ESTRELA, C. Ciência endodôntica. São Paulo: Artes Médicas, 2004.

BERNABÉ, P.F.E.; HOLLAND, R. MTA and Portland cement: considerations about physical, chemical and biological properties. São Paulo: Santos, 2003.

ABREU, M.J.N.; TAVARES, D.; VIEIRA, D.F. Radiopacity of restorative materials. Oper. Dent., Seattle, v. 2, no. 1, p. 3-16, Winter 1997.

HEHN, L. Comparação de três sistemas digitais em relação à densidade óptica de cimentos de ionômero de vidro. Rev. Odonto Ciênc., Porto Alegre, v. 22, no. 57, p. 233-237, jul./set. 2007.

LEITES, A.C. Radiopacidade do cimento Portland modificado em comparação com o MTA. Rev. Odonto Ciênc., Porto Alegre, v. 23, n. 2, p. 145-149, abr./jun. 2008.

AMERICAN NATIONAL STANDARD/AMERICAN DENTAL ASSOCIATION. Specification no. 57: Endodontic Filling Materials. Chicago, 2006.

IMPERIANO, M.T. et al. Comparative radiopacity of four low-viscosity composites. Braz. J. Oral Sci., Piracicaba, v. 6, no. 20, p. 1278-1282, Jan./Mar. 2007.

ESPELID, I. et al. Radiopacity of restorations and detection of secondary caries. Dent. Mat., Copenhagen, v. 7, no. 2, p. 114-117, Apr. 1991

RASIMICK, B.J. et al. Radiopacity of endodontic materials on film and a digital sensor. J. Endod., New York, v. 33, no. 9, p. 1098-1101, Sept. 2007.

TORABINEJAD, M. Physical and chemical properties of a new rootend filling material. J. Endod., New York, v. 21, no. 7, p. 349-353, July 1995 .

TANOMARU J.M. et al. Evaluation of the radiopacity of root canal sealers by digitization of radiographic images. J. Appl. Oral Sci., n.12, v.4, p.355-7, dez. 2004.

ISLAM, I.; CHNG, H.K.; YAP, A.U.J. Comparison of the physical and mechanical properties of MTA and Portland cement. J. Endod., New York, v. 32, no. 3, p. 193-197, Mar. 2008.

TIRAPELLI, C. et al. Radiopacity and microhardness changes and effect of X-ray operating voltage in resin-based materials before and after the expiration date. Mat. Res., São Carlos, v. 7, no. 3, p. 409412, July/Sept. 2004.

SAIDON, J. Cell and tissue reactions to mineral trioxide aggregate and Portland cement. Oral Surg. Oral Med. Oral Pathol. Oral Radiol. Endod., St. Louis, v. 95, no. 4, p. 483-489, Apr. 2003. 
FIGUEIREDO, J.A.P. de. et al. Avaliação da radiopacidade do cimento Portland comparado ao cimento MTA. ROBRAC, Goiânia, v. 17, n. 43 , p. 39-45, jun. 2008.

RUIZ, P.A. Perfurações endodônticas: revisão da literatura. Rev. Bras. Patol. Oral, Natal, v. 2, n. 2, p. 45-50, abr./jun. 2003.

MITTAL, M.; CHANDRA, S.; CHANDRA, S. An evaluation of plaster of Paris barriers used under various materials to repair furcation perforations (in vitro study). J. Endod., New York, v. 25, no. 5, p. 385388, May 1999.

TRINDADE, A.C.; OLIVEIRA, E.P.M. de; FIGUEIREDO, J.A.P. de. Análise comparativa da resposta tecidual ao agregado trióxido mineral (MTA) e ao cimento Portland, isolado e acrescido de substância radiopatizante. JBE: j. bras. endodontia, Curitiba, v. 4, n. 15, p. 309-314, out./dez. 2003.

GUIMARÃES, C.S. Análise objetiva e subjetiva do MTA e cimento Portland em sistemas radiográficos convencional e digital. Camaragibe. 2009. 83 p. Tese (Mestrado em Endodontia)- Faculdade de Odontologia de Pernambuco, Universidade de Pernambuco, Camaragibe, 2009.

AMERICAN NATIONAL STANDARD/AMERICAN DENTAL ASSOCIATION. Specification no. 57: Endodontic Filling Materials. Chicago, 1983.

DOYLE, P.; FINNEY, L. Performance evaluation and testing of digital intra-oral radiographic systems. Radiat. Prot. Dosimetry, Oxford, v. 117, no. 1-3, p. 313-317, 2005.

GIUSTI, E.C.; FERNANDES, K.P.S.; MARQUES, J.L.L. Medidas eletrônica e radiográfica digital na odontometria: análise in vivo. RGO, Porto Alegre, v. 55, n. 3, p. 239-246, jul./set. 2007.

Rev. Fac. Odontol. Porto Alegre, v. 51, n. 3, p. 11-15, set./dez., 2010. 